\title{
A Comparative Physicochemical and Pharmacognostical Evaluation of Nishamalaki - An Ayurvedic Antidiabetic Formulation
}

\author{
Venkateshwarlu $\mathbf{G}^{1 *}$, Venkata Narasimhaji $\mathrm{CH}^{1}$, Shantha $\mathrm{TR}^{1}$, Kishore $\mathrm{KR}^{1}$, \\ Prathapa Reddy $\mathrm{M}^{1}$ and Raghavendra $\mathrm{HL}^{2}$
}

${ }^{1}$ National Ayurveda Dietetics Research Institute, Jayanagar, Bangalore-560011, Karnataka, India

${ }^{2}$ College of Health and Medical Science, Post Box No: 395, Wollega University, Nekemte, Ethiopia

\begin{tabular}{|c|c|}
\hline Abstract & Article Information \\
\hline \multirow{3}{*}{$\begin{array}{l}\text { Most of the traditional systems of medicine are effective but they require } \\
\text { standardization. Standardization of an herbal formulation is essential in order to } \\
\text { assess the quality of drugs, based on the amount of their active principles, } \\
\text { physicochemical standards and pharmacognostical parameters. This article reports on } \\
\text { standardization and comparative study of the prepared herbal formulation nisamalaki } \\
\text { churna which is used as anti-diabetic ayurvedic formulation with standard formulation } \\
\text { (IMPCOPS). These two batches of nisamalaki churna are standardized and } \\
\text { comparative study was done on the basis of organoleptic, Physicochemical } \\
\text { properties, TLC, macro and microscopic powder studies. }\end{array}$} & $\begin{array}{l}\text { Article History: } \\
\text { Received : } 10-08-2013 \\
\text { Revised : } 27-09-2013 \\
\text { Accepted : } 29-09-2013 \\
\end{array}$ \\
\hline & $\begin{array}{l}\text { Keywords: } \\
\text { Ayurvedic Formulation } \\
\text { Antidiabetic } \\
\text { Phytochemical }\end{array}$ \\
\hline & $\begin{array}{l}{ }^{*} \text { Corresponding Author: } \\
\text { Venkateshwarlu G } \\
\text { E-mail: } \\
\text { nadri.bengaluru1@gmail.co }\end{array}$ \\
\hline
\end{tabular}

\section{INTRODUCTION}

India is in rich heritage of traditional medicine and Ayurveda is one of the well-developed ancient systems of medicine. The quality assessment of ayurvedic/herbal formulation is of a very importance in order to justify their acceptability in modern system of medicine. The World Health organization (WHO) has appreciated the importance of medicinal plants for public health care in developing nations and has evolved guidelines to formulate the national policies on traditional medicine. In India, the department of AYUSH, Government of India, framed protocols to develop standard operating procedures for the manufacturing process to develop pharmacopeial standards for ayurvedic preparations

Diabetes mellitus, often simply referred to as diabetes, is a group of metabolic diseases in which a person has high blood sugar, either because the body does not produce enough insulin, or because cells do not respond to the insulin that is produced. This high blood sugar produces the classical symptoms of polyuria (frequent urination), polydipsia (increased thirst) and polyphagia (increased hunger) (Cooke and Plotnick, 2008).
Very few reputed companies produce Nisha Amalaki in India and IMPCOPS (Indian Medicinal Practitioner's Co-Operative Pharmacy \& Stores Ltd) based in Chennai (South India) produces this formulation in the form of a tablet. The Amalaki (fruits of embelica officinalis) and Nisha (rhizomes of curcuma longa) are also native to Karnataka (South India). Till now there has been no documentation on Physicochemical and Pharmacognostical evaluation to set standards for this polyherbal formulation and compare the classically prepared nisha amalaki with the market available sample using this parameters and understand whether there are any differences.

Hence this study presents methods of preparation of a Ayurvedic polyherbal antidiabetic formulation called as Nisha Amalaki as per classical method, preliminary standardization of the preparation employing physicochemical, Pharmacognostical and TLC parameters according to WHO protocol and comparing the same with that of available market sample [Indian Medicinal Practitioner's Co-Operative Pharmacy \& Stores Ltd (batch-APT 227)] of the same preparation. 
Venkateshwarlu et al.,

Ayurveda prescribes a poly-herbal formulation called Nisha Amalaki churna (available in powder form or tablet form) for diabetes. It consists of fine powders of Curcuma longa (Turmeric) and Emblica officinalis each in equal proportion (Vaidya Yoga Ratnavali, 2000).

Amalaki (Indian Goose Berry) is one of the ingredients of nisamalaki churna, ithas been considered the best of the ayurvedic rejuvenative herbs, because it is tridosaghna. Uniquely, it has a natural balance of tastes (sweet, sour, pungent, bitter and astringent) all in one fruit, it stimulates the brain to rebalance the three main components of all physiological functions, the water, fire, and air elements within the body (Bajracharya, 1979). Because of its cooling nature, amla is a common ingredient in treatments for a burning sensation anywhere in the body and for many types of inflammation and fever; these are manifestations of pitta (fire) agitation (Williamson, 2002). The fruit is a very rich source of vitamin $C$ according to most if not nearly all references, this is probably not the case (Ghosal, Triphati and Chauhan, 1996). It was proposed that superior effect of the mistaken "vitamin C" component is actually the more stable and potent anti-oxidant effect of the tannins that appeared to be the vitamin. Its mineral and vitamin contents include calcium, phosphorous, iron, carotene, thiamine, riboflavin, and niacin. The fruits are rich in tannins, gallic acid and ellagic acid etc. The use of amla as an antioxidant has been examined by a number of authors (Bhattacharya et al., 1999).

The other and main ingredient of nisamalaki churna is Haridra (Turmeric) balances all the three doshas. Because of its hot potency; it pacifies kapha and vatadoshas; and because of mild laxative action and bitter taste it pacifies the pitta dosha. According to Ashtanga Samgraha; haridra is the best ayurveda medicine for treatment of all the metabolic disorders like diabetes. It is well known for its complexion enhancing action, anti-bacterial activity and healing qualities. Along with these it also possesses scraping action so help in removing the unwanted fats from the body; corrects metabolism and useful in anemia, diabetes and liver problems. The active constituents of turmeric are the flavonoid curcumin (diferuloylmethane) and various volatile oils, including tumerone, atlantone, and zingiberone. Other constituents include sugars, proteins, and resins. The best-researched active constituent is curcumin, which comprises 0.3-5.4 percent of raw turmeric (Leung, 1980).

\section{MATERIAL AND METHODS}

Physico-chemical studies like total ash, acid insoluble ash, water and alcohol soluble extract,
Sci. Technol. Arts Res. J., July-Sep 2013, 2(3): 69-78

loss on drying at $105{ }^{\circ} \mathrm{C}$ and successive extraction values by soxhelet extraction method were carried out as per WHO guide lines (WHO, 1998). Powder microscopy and preliminary phytochemical tests were performed as per the standard methods (Harbone, 1978).

\section{Plant Material}

Nisamalaki churna is poly herbal formulation, it consisting of 2 ingredients viz, Haridra (Curcuma longa) and Amalaki (Emblicaofficinalis) (Table 1).

Table 1: Ingredients of Nisamalaki churna.

\begin{tabular}{lccc}
\hline $\begin{array}{c}\text { Botanical name } \\
\text { of the Ingredient }\end{array}$ & $\begin{array}{c}\text { Sanskrit } \\
\text { name }\end{array}$ & $\begin{array}{c}\text { Part } \\
\text { used }\end{array}$ & $\begin{array}{c}\text { Quantity } \\
\text { (per 100 } \\
\text { gm) }\end{array}$ \\
\hline $\begin{array}{l}\text { Curcuma longa Linn. } \\
\text { Emblicaofficinalis Gaertn. }\end{array}$ & Amaridra & Root & $50 \mathrm{gm}$ \\
\hline
\end{tabular}

\section{Preparation of Formulation (Batch I)}

The drugs used in the preparation were procured from the SMP unit and cleaned and dried in shade and powdered separately. Each powder weighed in gms and sieved by using 22 No. Mesh according to the formulation and mixed uniformly and mixed well (Vaidya Yoga Ratnavali, IMPCOPS).

\section{Standard sample (Batch II)}

Standard market sample (Batch No APT 227) procured from IMPCOPS, Chennai, India.

\section{Standardization Parameters}

The various standardization parameters studied were organoleptic properties, physicochemical investigations, fluorescence analysis, \& preliminary phytochemical analysis, powder microscopic analysis, determination of $\mathrm{pH}$, moisture content and TLC studies.

\section{Organoleptic Evaluation}

The organoleptic characters of the samples were evaluated based on the method described by Siddiqui and Hakim et al. (1995). Organoleptic evaluation refers to evaluation of the formulation by colour, odour, taste and texture etc.

\section{Determination of $\mathrm{pH}$}

$10 \%$ solution of polyherbal formulation was prepared in distilled water and $\mathrm{pH}$ was determined using $\mathrm{pH}$ meter MICROPRO Lab Mate digital $\mathrm{pH}$ meter.

\section{Determination of Moisture Content}

Moisture content was determined by loss on drying (LOD) method (Mukherjee, 2002). $3 \mathrm{gm}$ of the weighed quantity of the drug was taken and kept in oven at $105{ }^{\circ} \mathrm{C}$ till a constant weight was obtained. Amount of moisture present in the sample was calculated as reference to the air dried drug. 
Venkateshwarlu et al.,

\section{Physicochemical Investigations}

Physico-chemical investigations of formulations were carried outwere thedetermination of extractive values and ash values (Indian Pharmacopoeia, 1996).

\section{Preliminary Phytochemical Analysis}

Preliminary qualitative phytochemical analysis of all the extracts was carried out by employing standard conventional protocols (Trease and Evans, 1978; Sazada et al., 2009 and Kokate, Purohit and Gokhale, 2006).

\section{Fluorescence Analysis and TLC Studies}

Fluorescence characters of powdered plant material with different chemical reagents were determined under ordinary and ultraviolet light (Chase and Pratt, 1949). $1 \mathrm{mg}$ of the poly herbal sample was taken in a glass slide and treated with various reagents for the presence of their fluorescence characters under ultra-violet lamp. TLC studies have been carried out according to Igon Stahl et al., (1969).

\section{Powder Microscopic Analysis}

For powder microscopic analysis, about 1 to 3 pinch of the sample was warmed with 2 to 4 drops of chloralhydrate solution, water and little safranin stain and observed under the microscope to identify the diagnostic features of the compound formulation for the presence of different fragments of tissues in curna. It was also observed by putting a pinch of phloroglucinol, 2 drops of concentrate dihydrochloric acid and few drops of alcohol for the presence of lignin containing tissues (Trease and Evans, 1978).

\section{RESULTS AND DISCUSSION}

Organoleptic evaluation was used for identification of sensory characteristics powder like colour, odour (smell), touch and taste. The taste of prepared sample (batch I) is bitter dominates than sour, whereas standard sample's (batch II) sour taste dominates then bitter (Table 2).

Table 2: Organoleptic characters.

\begin{tabular}{lcc}
\hline Entry & Batch-I & Batch-II \\
\hline Colour & Yellow & Mustered yellow \\
Odour & Characteristic & No smell \\
Touch & Smooth & Hard \\
Taste & Bitter and sour & Sour and bitter \\
\hline
\end{tabular}

\section{Microscopic Characters of Batch I \& II}

The polyherbal powder was treated with chloral hydrate, water and glycerin and microscopical examination was carried out for the presence of following different fragments of tissues. The batch-I (Figure 1(a-s)) has the correlation and all the characteristic features are comparable with the
Sci. Technol. Arts Res. J., July-Sep 2013, 2(3): 69-78

standard formulation (batch-II) in powder microscopy (Figure 2(a-s)).

The following important identifying characters were observed in microscopic examination Figure 1 (a-s) of prepared nisamalaki churna (batch-l). Different fragments of tissues.

- Different fragments of tissues like xylem vessels with helical type

- Fragments of Cork cells

- Parenchymatous cells

- Starch grains

- Reticulate xylem vessel

- Elongated xylem fiber

- Fragments spiral vessel

- Stone cells

- Epicarp cells

- Xylem vessel

- Yellow content

- Groups of stone cells.

- Epidermal cells Surface view

- Calcium oxalate crystal

- Reticulate xylem vessel

- Elongated fiber

The following important identifying characters were observed in microscopic examination Figure 2 (a-s) of nisamalaki churna tablet (batch-II). The tablet was crushed in to powder form and treated with 2-3 drops of Chloralhydrate solution, water and observed under the microscope following fragments of different tissues were observed.

- Groups of fibers

- Different fragments of tissues with stone cells, starch grains, thin walled parenchymatous cells, fibers

- Stone cells

- Thin walled parenchymatous cells

- Single fiber

- Thin walled parenchymatous cells and branched fibers

- Thin walled parenchymatous cells

- Groups of xylem fibers

- Epicarp cells surface view

- Cork cells

- Reticulate xylem vessel

- Calcium oxalate crystal

- Yellow content of tannin

- Different fragments of tissues like reticulate vessel, starch grains and parenchymatous cells

- Different fragments of tissues like fibers, starch grains, Parenchymatous cells

- Elongated fiber

- Groups of Stone cells

Therefore there were no significant differences in the two batches of samples with respect to powder microscopic studies 
Venkateshwarlu et al.,

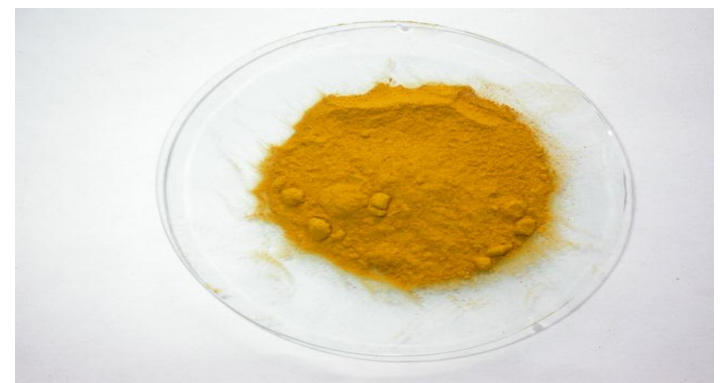

a) Macroscopy of the Nisamalakichurna

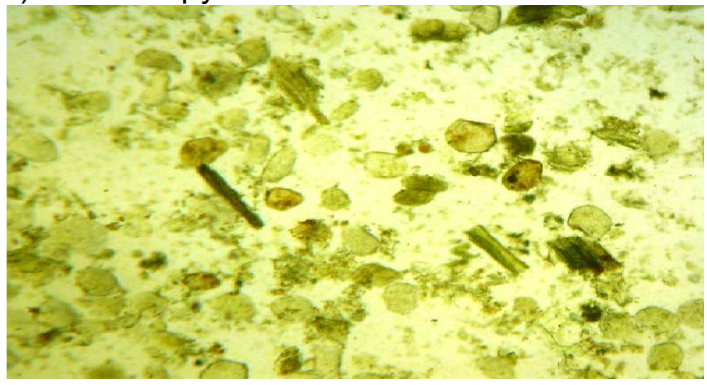

c) Different fragments of tissues.10x $\times 10 x$

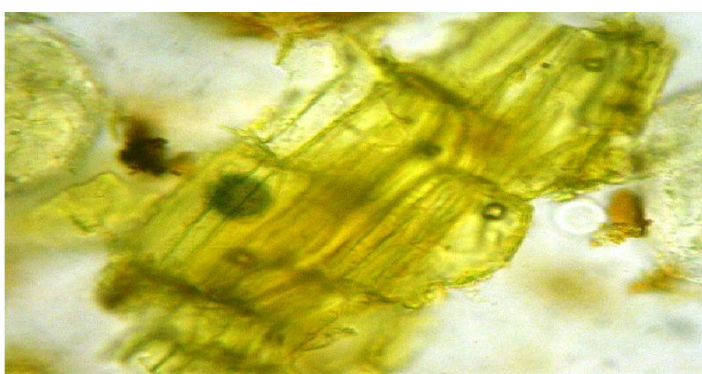

e) Fragments of Cork cells.10x X $10 x$

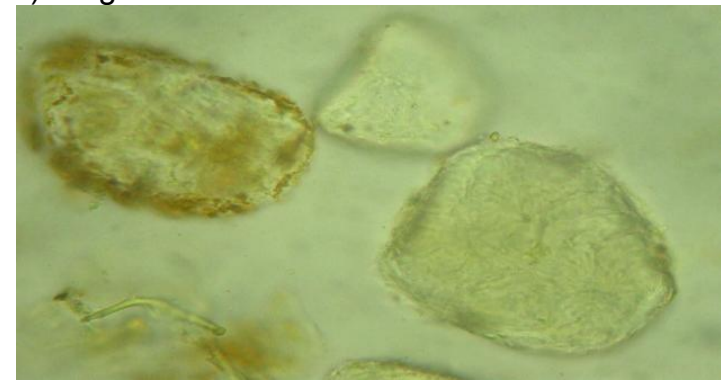

g) Starch grains $10 X \times 40 X$

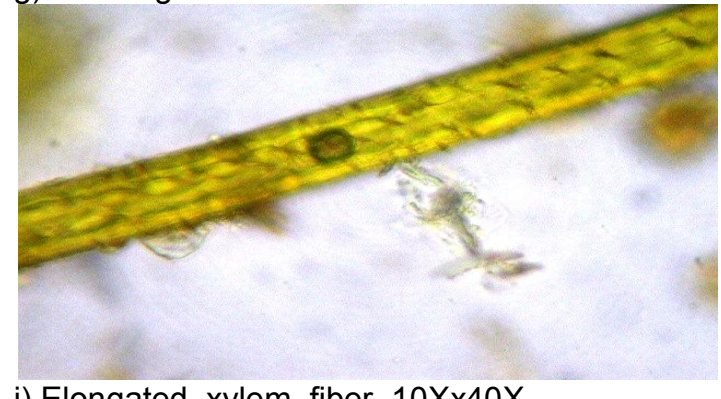

i) Elongated xylem fiber. 10Xx40X
Sci. Technol. Arts Res. J., July-Sep 2013, 2(3): 69-78

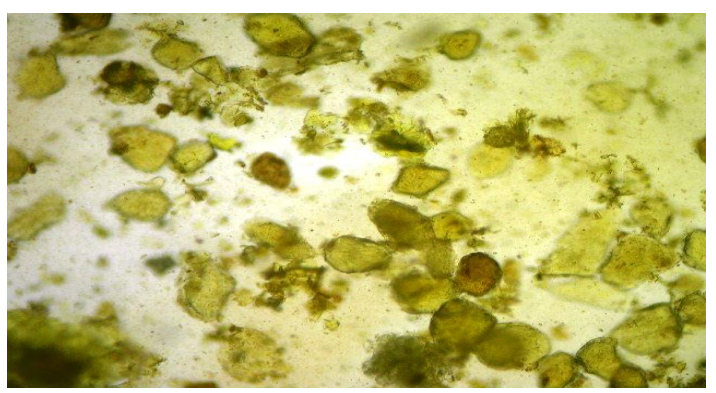

b) Different fragments of tissues.10x X 10x

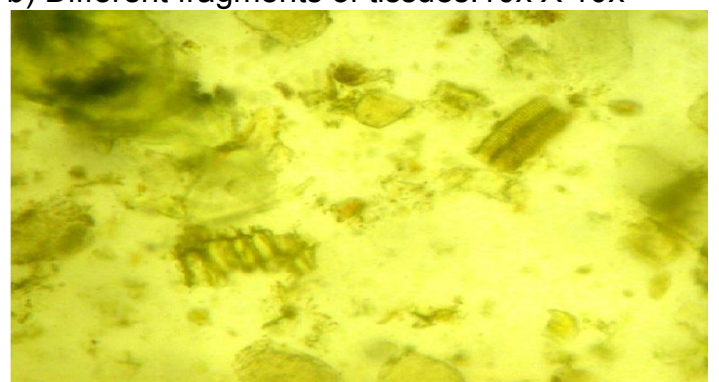

d) Fragments of tissues like xylem vessels and helical vessels. $10 \times \times 10 \times$

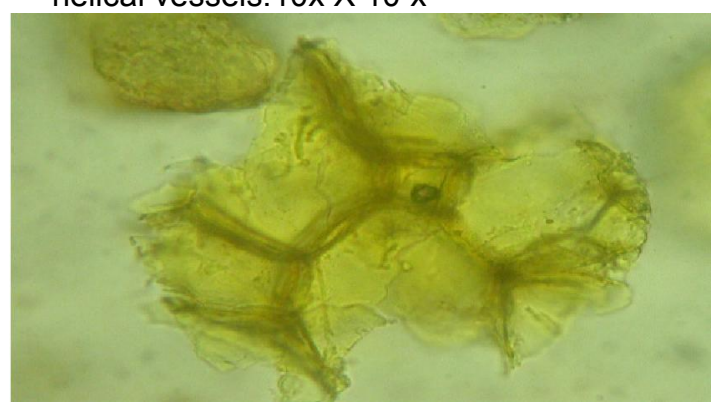

f) Parenchymatous cells.10x X $10 x$

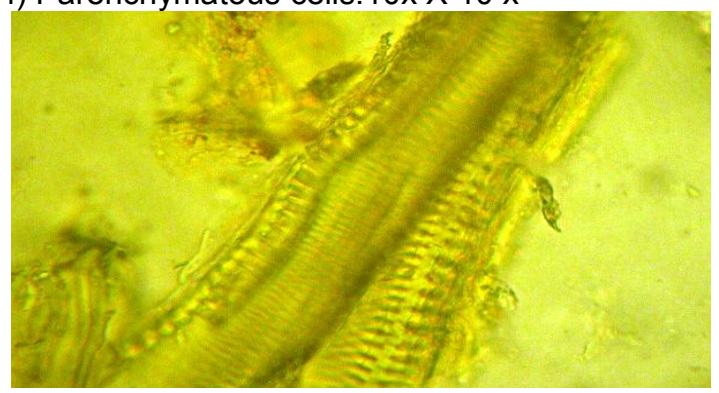

h) Reticulate xylem vessel.

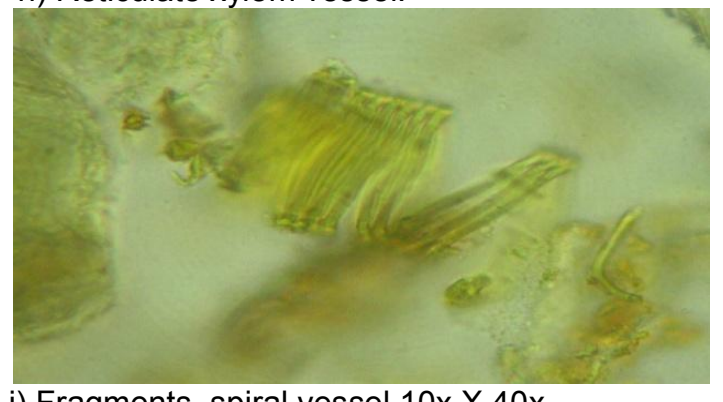

j) Fragments spiral vessel 10x $\times 40 x$ 
Venkateshwarlu et al.,

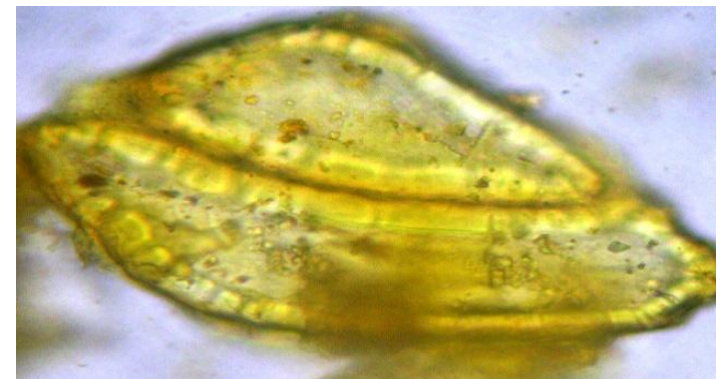

k) Stone cells $10 x \times 40 x$

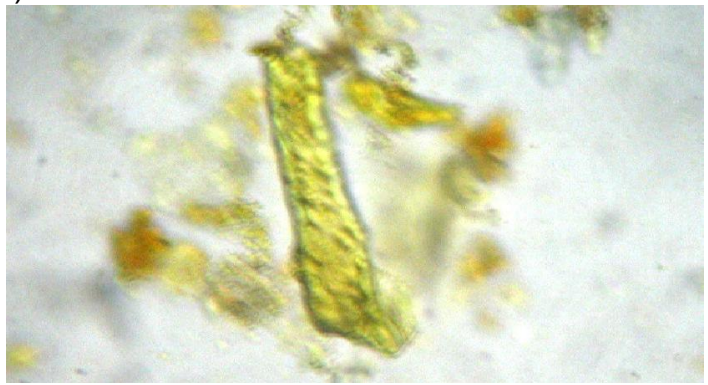

m) Xylem vessel $10 x \times 10 x$

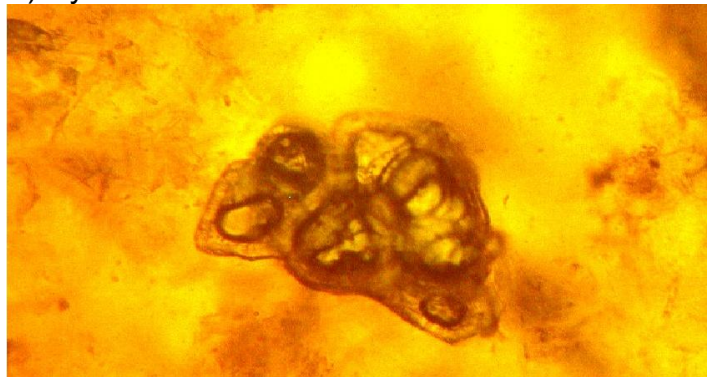

o) Groups of stone cells.10x X 40 x

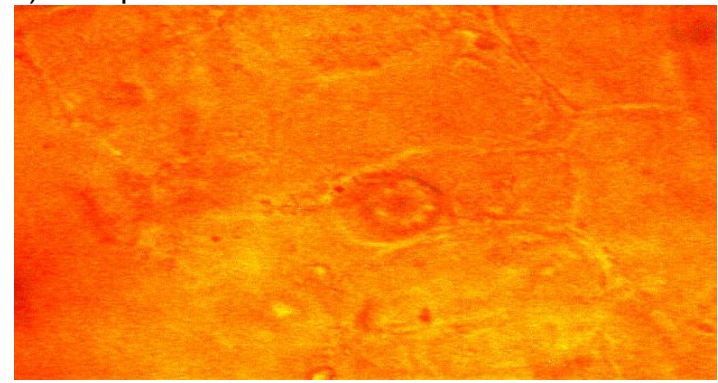

q)Calcium oxalate crystal $10 \times \times 40 \times$
Sci. Technol. Arts Res. J., July-Sep 2013, 2(3): 69-78

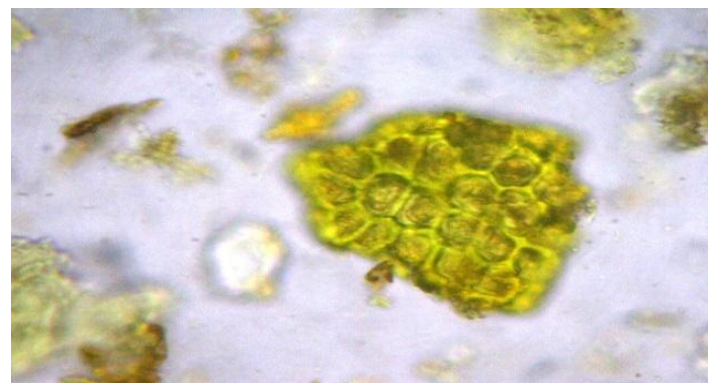

I) Epicarp cells $10 x \times 10 x$

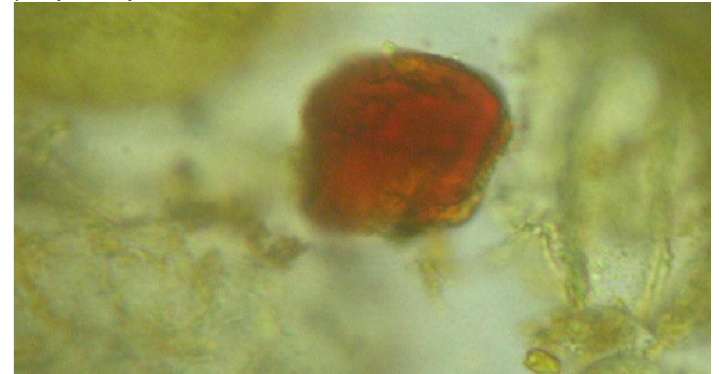

n) Yellow content $10 x \times 10 x$

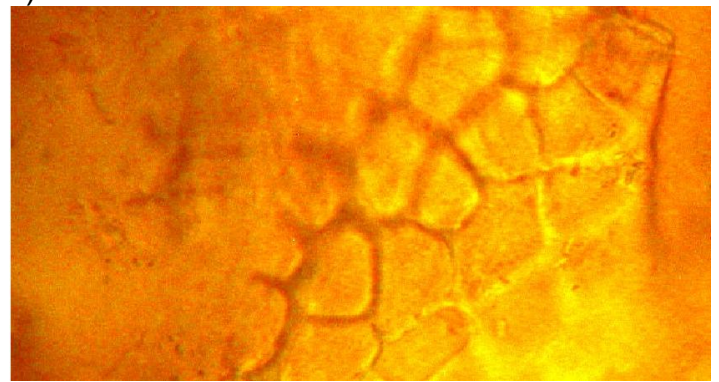

p) Epidermal cells Surface view10x X $40 x$

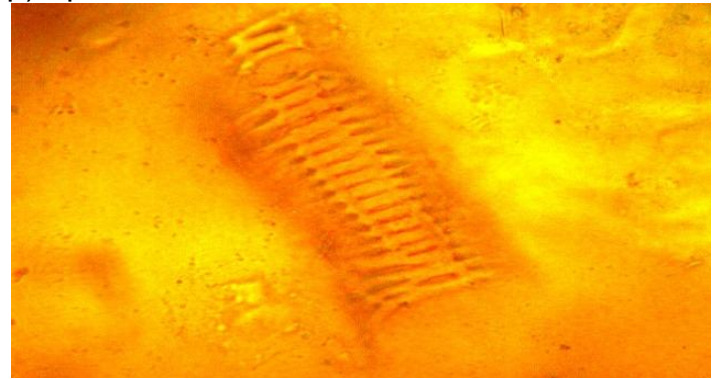

r) Reticulate xylem vessel. 10x X $40 x$

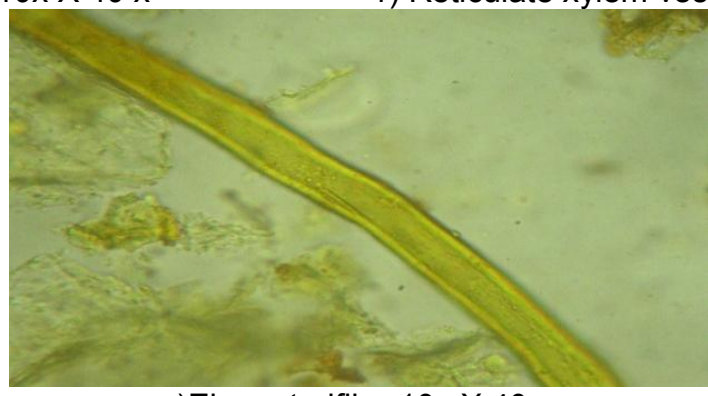

s)Elongatedfiber10x X 40 x

Figure 1(a-s): Powder microscopy of Batch-I (nisamalaki churna). 
Venkateshwarlu et al.,

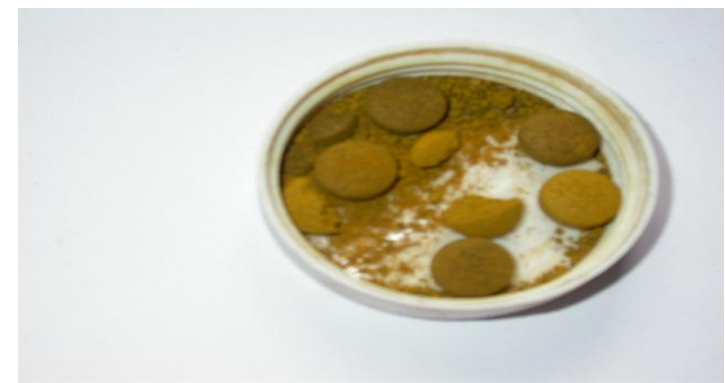

a) Nishamalaki tablets sample

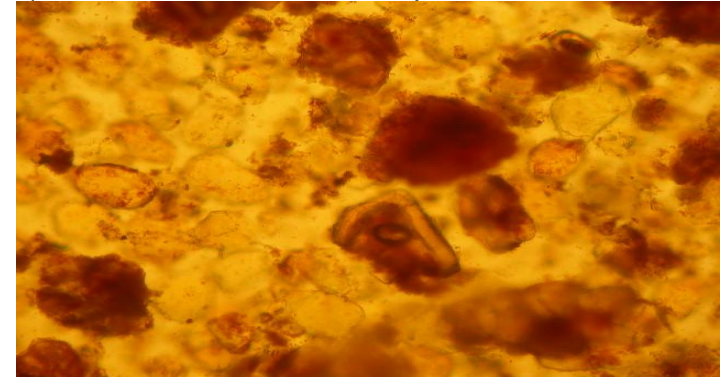

c) Different fragments of tissues with stone cells, starch grains, thin walled parenchymatous cells, fibers. 10x X10x

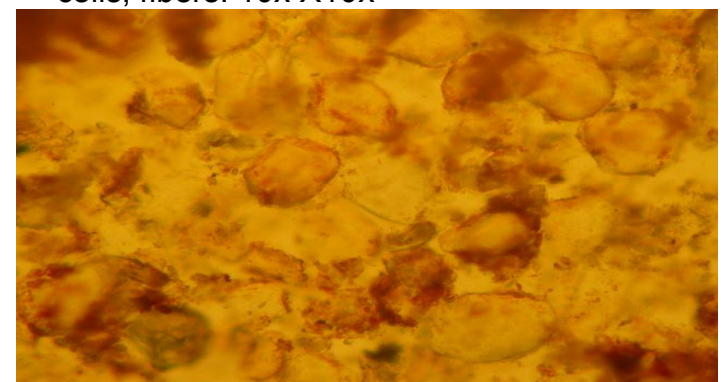

e) Thin walled parenchymatous cells. 10x X10x

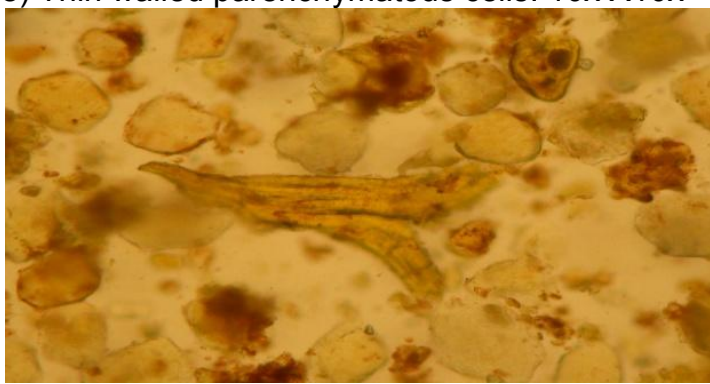

g) Thin walled parenchymatous cells and branched fibers. 10x X10x

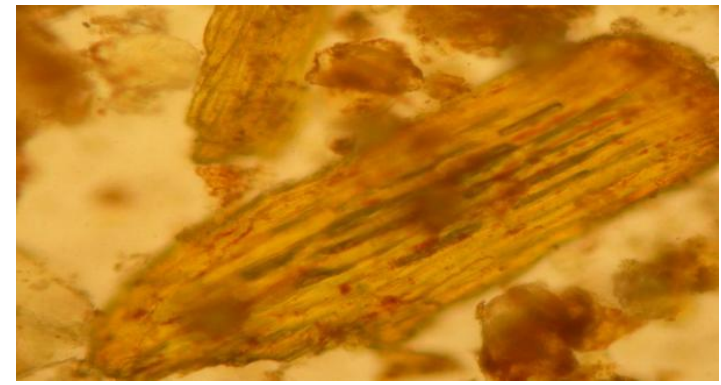

i) Groups of xylem fibers. 10Xx10X
Sci. Technol. Arts Res. J., July-Sep 2013, 2(3): 69-78

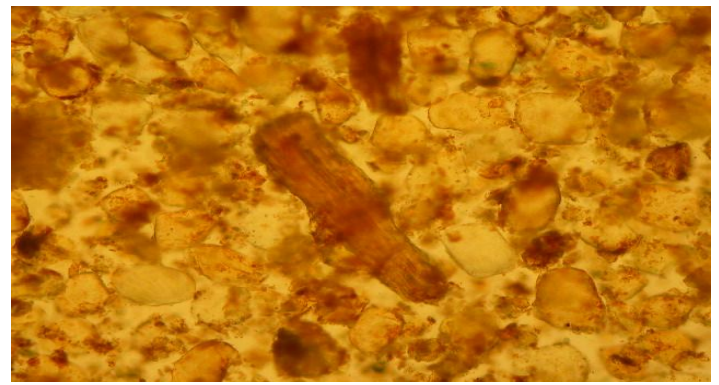

b) Groups of fibers $10 x \times 10 x$

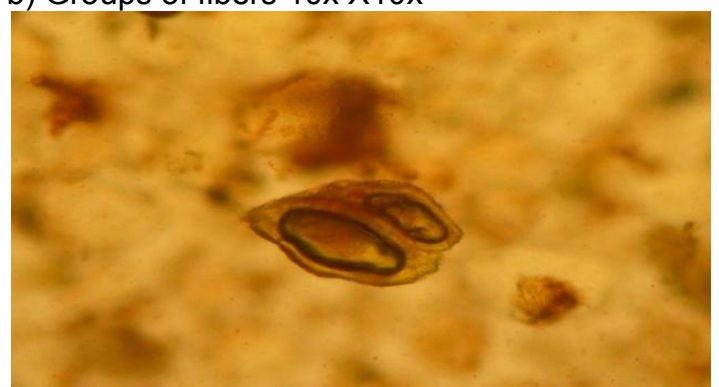

d) Stone cells $10 x \times 10 x$

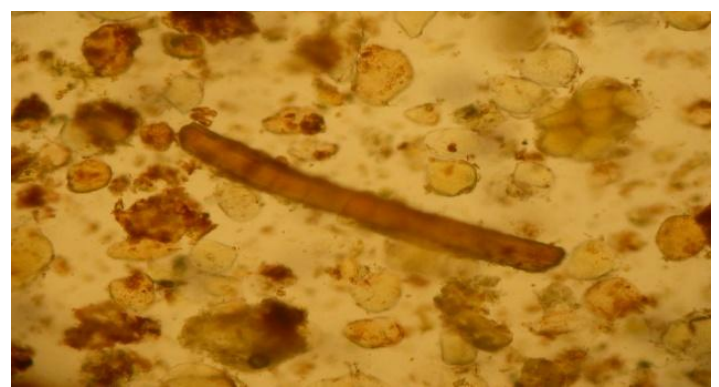

f) Single fiber. $10 x \times 10 x$

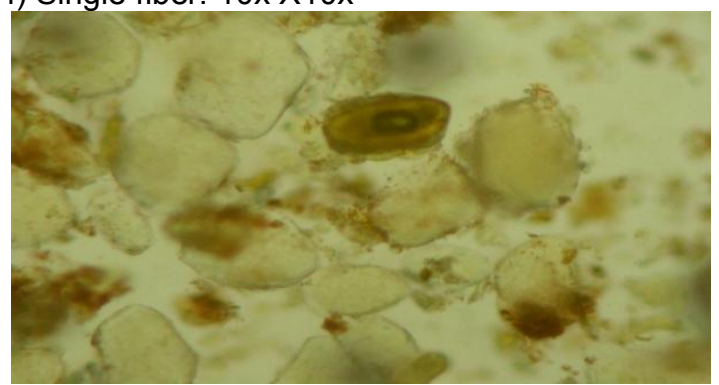

h) Thin walled parenchymatous cells.10xX10x

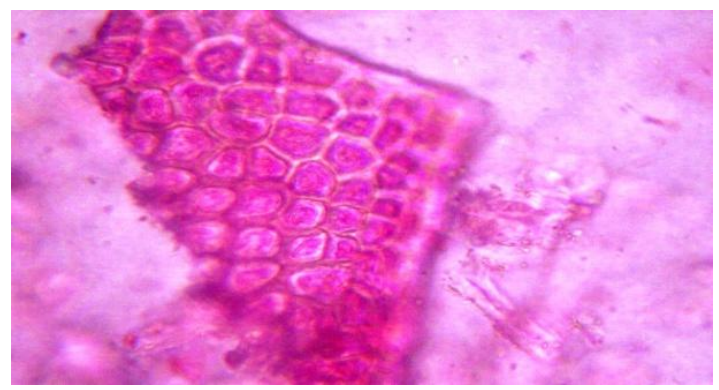

j) Epicarp cells surface view. 
Venkateshwarlu et al.,

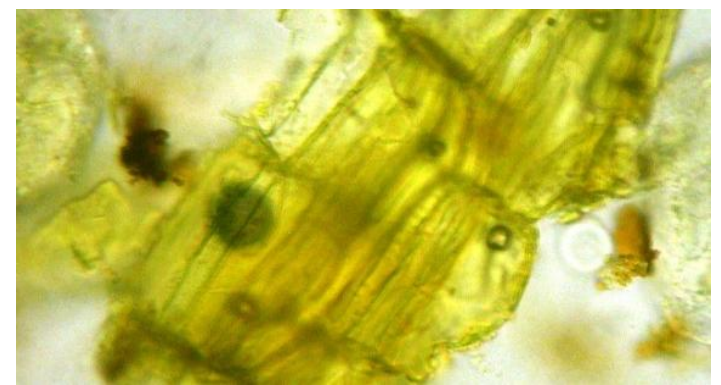

\section{k) Cork cells}

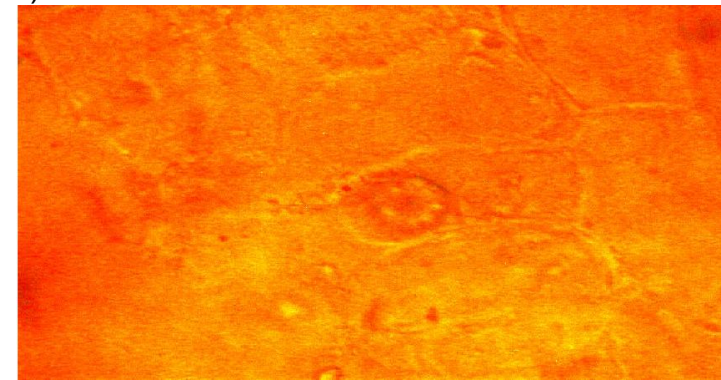

m) Calcium oxalate crystal. 10x X10x

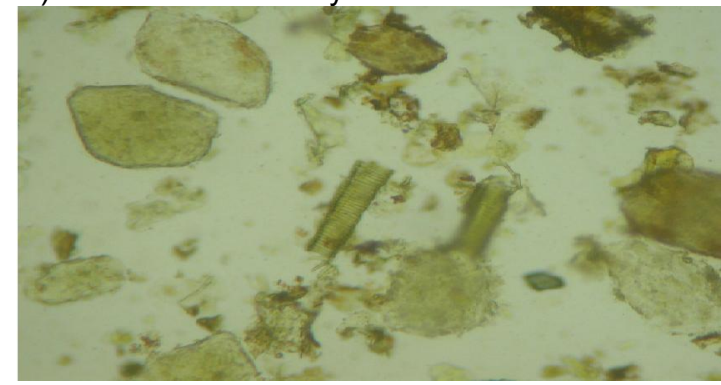

o) Fragments of tissues like reticulate vessel, starch grains and parenchymatous cells. 10xX 40x

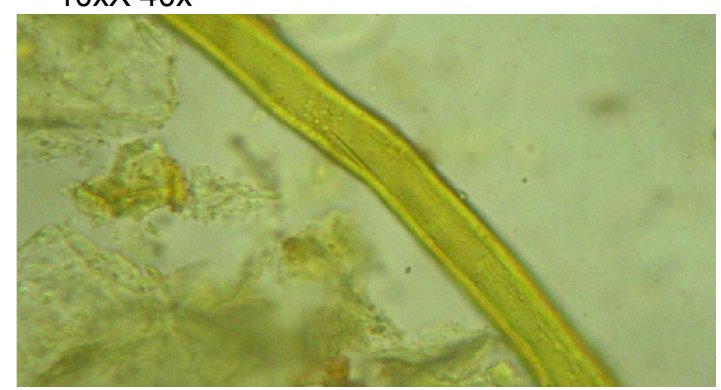

q) Elongated fiber.10x $\times 40 x$
Sci. Technol. Arts Res. J., July-Sep 2013, 2(3): 69-78

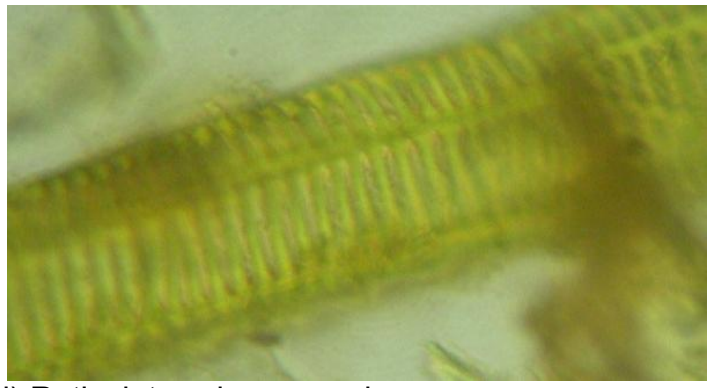

I) Reticulate xylem vessel.

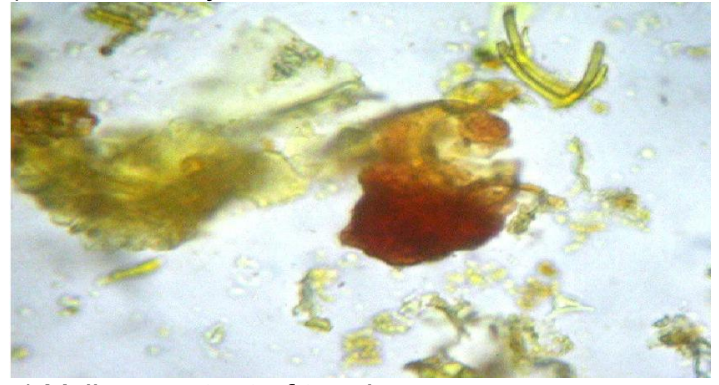

n) Yellow content of tannin.

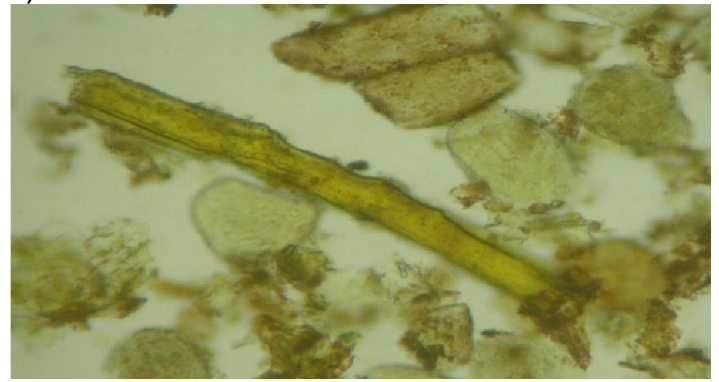

p) Fragments of tissues like fibers, starch grains, Parenchymatous cells.

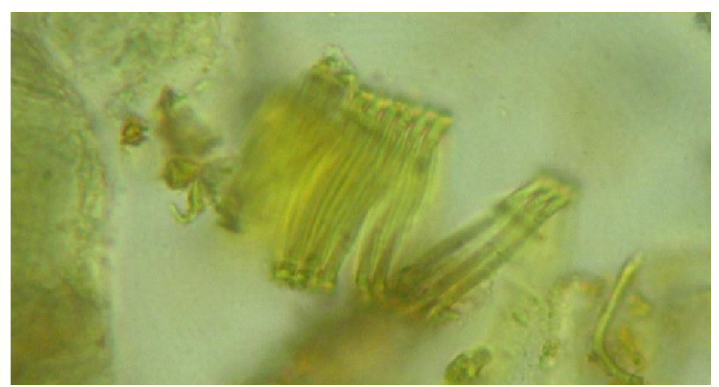

r) Spiral xylem vessel10x X 40x

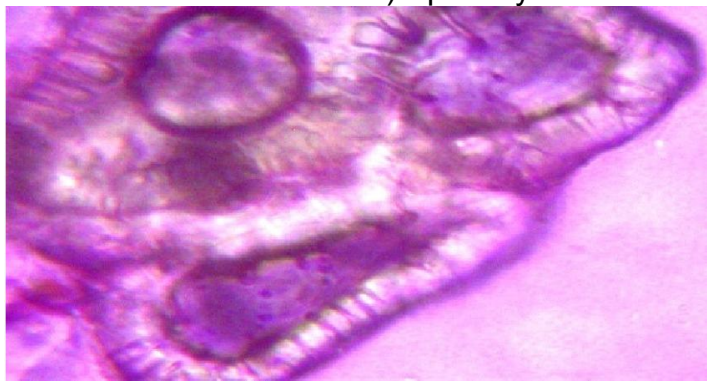

s) Groups of stone cells. $10 x \times 40 x$

Figure 2 (a-s): Powder microscopy of standard sample Batch-II (Tablet). 
Venkateshwarlu et al.,

Physicochemical \& Preliminary Phytochemical Studies

The physicochemical studies were carried out for both the batches (prepared and standard market sample) and the observations of prepared one are comparable with the standard market sample, and are given in table 3 . The test for percentage of moisture content (loss on drying) determines both water and volatile matter. Total ash measures the amount of materials remaining after ignition. Acid insoluble ash measures the amount of silica present especially sand and siliceous matter. Extractive
Sci. Technol. Arts Res. J., July-Sep 2013, 2(3): 69-78

values were examined which are useful for evaluation of nature of chemical constituents present in drug (Table 3).

Preliminary phytochemical screening of compound formulation was identified through qualitative chemical analysis indicated the presence of alkaloids, carbohydrates, flavonoids, terpenoids, resins, saponins, steroid and tannins etc., of both the batches (Table 4). The physicochemical constituents in both the samples were comparable.

Table 3: Physicochemical Parameters.

\begin{tabular}{clcc}
\hline \multirow{2}{*}{ SI.No. } & \multicolumn{1}{c}{ Test } & \multicolumn{2}{c}{ Result } \\
\cline { 3 - 4 } & & Batch-I & Batch-II \\
\hline 1 & \%Loss on drying at $105^{\circ} \mathrm{C}$ & 10.38 & 8.16 \\
2 & \%Total- ash & 5.53 & 5.1 \\
3 & \%Acid- insoluble ash & 0.425 & 0.41 \\
4 & \%Water- soluble extractive & 18.6 & 19.8 \\
5 & \%Alcohol- soluble extractive & 10.84 & 10.82 \\
6 & pH (10\% aqueous solution) & 2.91 & 3.01 \\
& Successive extraction & & \\
7 & \%Petroleum ether 60-80 ${ }^{\circ} \mathrm{C}$ & 1.42 & 0.88 \\
& \%Chloroform & 2.38 & 1.21 \\
& \% Ethyl alcohol & 28.25 & 13.0 \\
8 & TLC & Table 4 and & Table 4 and \\
& & Fig. 3 (a-c) & Fig. 3 (a-c) \\
\hline
\end{tabular}

Table 4: Preliminary Phytochemical constituents of Nishamalki churna.

\begin{tabular}{cllcc}
\hline SI.No & $\begin{array}{l}\text { Phytochemical } \\
\text { Constituent }\end{array}$ & Solvents Extract & Batch I & Batch II \\
\hline 1 & Crabohydrates & Aqueous & + & + \\
2 & Tannins & Aqueous/alcoholic & + & + \\
3 & Phenols & Alcoholic & + & + \\
4 & Steroids & Chloroform & + & + \\
5 & Triterpenoids & Petether & + & + \\
6 & Racins & Alcoholic & + & + \\
7 & Flavonoids & Alcoholic & + & + \\
8 & Alkaloids & Aqueous/alcoholic & - & - \\
9 & Acids & Aqueous & + & + \\
10 & Saponins & Aqueous & + & + \\
11 & Starch & Aqueous/ & + & + \\
\hline
\end{tabular}

\section{Fluorescence Analysis}

The fluorescence behavior of the powdered drug of both batches I \& II (prepared sample and standard sample) in different solutions towards ordinary light and Ultra Violet light (both long 365 $\mathrm{nm}$ and short $254 \mathrm{~nm}$ wave lengths) were observed and both the batches are exhibited in same color to different chemical reagents (Table 5).
Thin Layer Chromatographic Studies (TLC)

TLC studies were carried out by observing comparatively with standard market sample extracts of petroleum-ether, chloroform and ethanol solvents under successive extraction through soxhlet apparatus. TLC plates were observed in various mobile phase for all three different extracts of both batches by keeping two tracks (left track is sample prepared and right track is standard sample) on one plate to develop chromatogram and correlate.TLC of 
Venkateshwarlu et al.,

petroleum-ether extract of both the batches were observed in mobile phase hexane: ethyl acetate $(4: 1)$, and showed 5 spots with $R_{f}(0.02$ to 0.47 ) Figure 3 (a) (entry a, Table 6); TLC of chloroform extract of both batches were observed in mobile phase hexane: ethyl acetate (3:2) with one spot $R_{f}(0.22)$ Figure 3 (b) (entry b, Table 6); TLC of ethanol-extract extract of both the batches were observed in mobile phase chlorofrom: methanol + farmic acid (3drops) (17:3) with four spots $R_{f}(0.03$ to 0.82 ) Figure 3 (c) (entry c, Table 6). TLC of samples belonging to both batches with petroleumether extract observed in mobile phase hexane:
Sci. Technol. Arts Res. J., July-Sep 2013, 2(3): 69-78

ethyl acetate $(4: 1)$ revealed that the classically prepared nisha amalaki sample had a compound corresponding to $\mathrm{Rf}$ value 0.47 whereas the market sample consisted of a compound corresponding to Rf value: 0.46 . Similarly when TLC of ethanolextract extract of both the batches were observed in mobile phase chlorofrom: methanol + farmic acid (3drops) (17:3) the classically prepared nisha amalaki sample had compounds corresponding to Rf value 0.27 and 0.82 whereas, the market sample consisted of compounds corresponding to Rf values: 0.26 and 0.80 . Further studies with HPTLC will help decipher exact nature of these compounds.

Table 5: Fluorescence studies of batch-I and II.

\begin{tabular}{|c|c|c|c|c|}
\hline $\begin{array}{l}\text { SI } \\
\text { No. }\end{array}$ & Sample + Reagent & Ordinary light & $\begin{array}{c}\text { UV Long wave } \\
365 \mathrm{~nm}\end{array}$ & $\begin{array}{c}\text { U.V. Short wave } \\
254 \mathrm{~nm}\end{array}$ \\
\hline 1 & Powder as such & Yellow & Green & Yellowish green \\
\hline 2 & Powder + Water & Yellow & Fluorescent green & Fluorescent green \\
\hline 3 & Powder $+1 \mathrm{~N} . \mathrm{HCl}$ & Yellow & Green & Fluorescent green \\
\hline 4 & Powder $+1 \mathrm{~N} . \mathrm{NaOH}$ & Yellowish red & Blue & Brown \\
\hline 5 & Powder + $1 \mathrm{~N} \mathrm{NaOH}$ in $\mathrm{MeOH}$ & Yellowish red & Yellowish green & Greenish brown \\
\hline 6 & Powder $+50 \% \mathrm{KOH}$ & Yellowish red & Blue & Brown \\
\hline 7 & Powder + 50\% H2SO4 & Pinkish red & Black & Black \\
\hline 8 & Powder + Con. H2SO4 & Reddish black & Black & Black \\
\hline 9 & Powder $+50 \%$ HNO3 & Yellow & Black & Fluorescent green \\
\hline 10 & Powder + Con. $\mathrm{HNO} 3$ & Reddish yellow & Black & Fluorescent green \\
\hline 11 & Powder + Acetic acid & Yellowish brown & Yellow & Greenish yellow \\
\hline 12 & Powder + lodine water & Reddish brown & Black & Greenish yellow \\
\hline
\end{tabular}
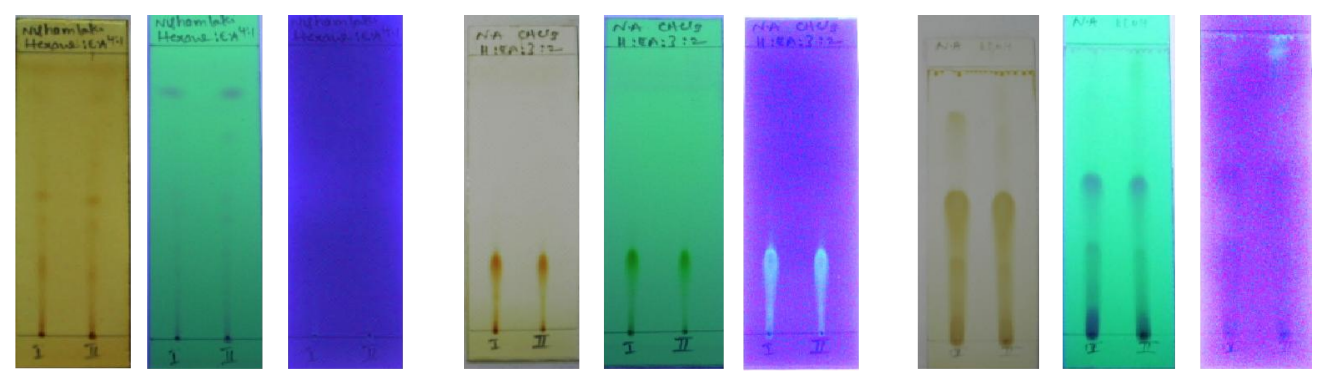

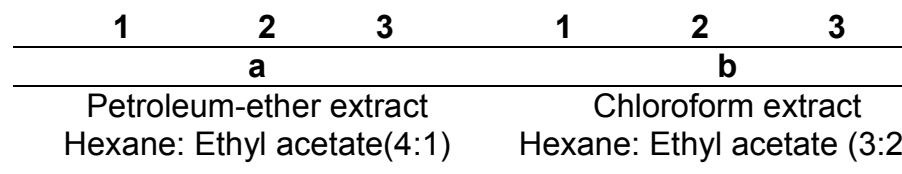

Figure 3 (a-c): TLC Plates 1, 2, 3 are observed under lodine vapor, short and long wave UV respectively. 
Table 6: TLC studies.

\begin{tabular}{|c|c|c|c|c|c|c|}
\hline \multirow[b]{2}{*}{ Entry } & \multirow[b]{2}{*}{ Extractives } & \multirow[b]{2}{*}{ Adsorbent } & \multirow[b]{2}{*}{ Solvent System } & \multirow{2}{*}{$\begin{array}{l}\text { Viewing } \\
\text { Medium }\end{array}$} & \multirow{2}{*}{\multicolumn{2}{|c|}{$\begin{array}{c}\text { Rf. Values } \\
\text { [lodine-Medium] }\end{array}$}} \\
\hline & & & & & & \\
\hline a & $\begin{array}{l}\text { Petroleum- } \\
\text { ether } \\
60-80^{\circ} \mathrm{C}\end{array}$ & $\begin{array}{l}\text { Silica gel } 60 \mathrm{~F}_{254} \\
\text { pre coated sheets }\end{array}$ & $\begin{array}{l}\text { Hexane: } \\
\text { Ethyl acetate }(4: 1)\end{array}$ & $\begin{array}{l}\text { lodine } \\
\text { vapour }\end{array}$ & $\begin{array}{c}0.02,0.06 \\
0.230 .37 \\
0.47 \\
\end{array}$ & $\begin{array}{c}0.02,0.06, \\
0.23,0.37 \\
0.46\end{array}$ \\
\hline b & Chloroform & $\begin{array}{l}\text { Silica gel } 60 \mathrm{~F}_{254} \\
\text { pre coated sheets }\end{array}$ & $\begin{array}{c}\text { Hexane: } \\
\text { Ethyl acetate (3:2) }\end{array}$ & $\begin{array}{l}\text { lodine } \\
\text { vapour }\end{array}$ & 0.22 & 0.22 \\
\hline c & Ethanol & $\begin{array}{l}\text { Silica gel } 60 \mathrm{~F}_{254} \\
\text { pre coated sheets }\end{array}$ & $\begin{array}{c}\text { Chlorofrom: } \\
\text { Methanol+ Farmic } \\
\text { acid (3drops) (17:3) }\end{array}$ & $\begin{array}{l}\text { lodine } \\
\text { vapour }\end{array}$ & $\begin{array}{l}0.03,0.27 \\
0.50,0.82\end{array}$ & $\begin{array}{l}0.03,0.26 \\
0.50,0.80\end{array}$ \\
\hline
\end{tabular}

\section{CONCLUSION}

Ayurvedic antidiabetic herbal formulation 'nisamalaki churna' was correlated with the standard IMPCOPS nisamalaki tablet with respect to all standardization parameters viz., organoleptic properties, physicochemical investigations, fluorescence analysis, and preliminary phytochemical analysis, powder microscopic analysis, determination of $\mathrm{p}^{\mathrm{H}}$, moisture content and TLC studies.

Likewise comparative microscopical studies on the poly herbal formulation nishamalaki churna and standard IMPCOPS nishamalaki tablet was carried out and revealed that thepresence of all most all identifying microscopical characters of the individual drugs namely amalaki, haridra and the standard IMPCOPS tablet. The TLC studies revealed that the $R_{f}$ values of the prepared nisamlaki churna correlated with that of the standard nisamalki tablet. It can be concluded that this type of study is of great importance in characterization of powdered individual drugs and helps in establishing the pharmacopoeial standards. The study also establishes the fact that the Nisha Amalaki formulation prepared classically in Karnataka state of India is comparable to that of the market sample prepared by IMCOPS Chennai in Tamil Nadu state of India.

\section{REFERENCES}

Bajracharya, M.B. (1979). Ayurvedic Medicinal Plants. Kathmandu; Piyusavarsi Ausadhalaya.

Bhattacharya, A., Chatterjee, A., Ghosal, S., Bhattacharya S.K. (1999). Antioxidant activity of active tannoid principles of Emblicaofficinalis (amla). Indian Journal of Experimental Biology 37(7): 676-680

Chase, C.R., Pratt, R.J. (1949). Fluorescence of powdered vegetable drugs with particular reference to development of a system of identification. Journal of American Pharmacetical Association 38: 324- 331.

Cooke, D.W., Plotnick, L. (2008). Type 1 diabetes mellitus in pediatrics. Pediatric Reviews 29(11): 374-84.
Ghosal, S., Triphati V.K., Chauhan, S. (1996). Active constituents of Emblicaofficinalis: Part 1- The chemistry and antioxidative effects of two new hydrolysable tannins, Emblicanin A and B. Indian Journal of Chemistry 35B: 941-948.

Harbone, J.B. (1973). Phytochemical Methods, Jackman H. (Ed.), London; 1973, 70p.

Igon Stahl. (1969). Thin Layer Chromatography, A Laboratory Handbook. Springer Verlag Student ed. Berlin Springer Verlag; 52-86 and127-128.

Indian Pharmacopoeia (1996). Ministry of Health and Family Welfare. New Delhi; Government of India.

Kokate, C.K., Purohit, A.P., Gokhale, S.B. (2006). Pharmacognosy. $34^{\text {th }}$ ed.Pune, India; Nirali Prakashan.

Leung, A. (1980). Encyclopedia of Common Natural Ingredients Used in Food, Drugs, and Cosmetics. New York, NY: John Wiley; pp.313-314.

Mukherjee, P.K. (2002). Quality control of herbal drugs. I ed. Business horizons publishers; pp195-196.

Sazada, S., Arti, V., Ayaz, A., Faraha, J., Maheswari, M.K. (2009). Preliminary Phytochemical analysis of Some Medicinal and Aromatic Plants. Advances in Biological Research 3(5-6): 188-5.

Siddiqui and Hakim, M.A. (1995). Format for the pharmacopoeial analytical standards of compound formulation, workshop on standardization of Unani drugs (appendix). New Delhi; Central Council for Research in Unani Medicine (CCRUM); 24-25 January, 1995.

Trease, E.G., Evans, W.C. (1978). Pharmacognosy. 11th ed. BailliereTindall; London; pp.115-222.

Vaidya Yoga Ratnavali (Formulary of Ayurveda medicines). (2000). Chennai; The Indian Medicinal Practitioner's Co-Operative Pharmacy \& Stores Ltd; pp. 116.

Williamson, E.M. (2002). Major Herbs of Ayurveda. Churchill-Livingstone; London.

WHO (1998). Quality Control Methods for Medicinal Plant Materials. World Health Organization, Geneva; Pp. 2528 